of individual freedom to a class project of market freedom and capital accumulation. Hence, he suggests at one point in his argument that even the opposition to neoliberalism employs a discourse of individual human rights which can be absorbed 'within the neoliberal frame' (p. 178). At one stage Harvey expresses scepticism about 'rights talk' and universal rights, then at another he suggests that opposition to neoliberalism should take up an alternative 'bundle of rights' focusing on rights of free speech and democratic control. But surely these are also universal rights and can be justified as such in opposition to the rights highlighted in the neoliberal project? It is issues like these that readers primarily concerned with political theory might want to see more fully discussed than they are in this brief history of neoliberalism. But it cannot be denied that within a short compass Harvey has given a highly convincing diagnosis and interpretation of the neoliberal project. $\mathrm{He}$ pulls no punches in his picture of a world of privatization and insecurity, which he thinks can and must be opposed by a form of 'rejuvenated class politics' (p. 203).

John Schwarzmantel University of Leeds, UK

\title{
Archaeologies of the Future: The Desire Called Utopia and Other Science Fictions
}

Fredric Jameson

Verso, London \& New York, 2005, xvi $430 \mathrm{pp}$.

ISBN: 184460333.

Contemporary Political Theory (2007) 6, 264-268. doi:10.1057/palgrave.cpt.9300288

What is the work of the Utopian Imagination, of Utopian form, in contemporary politics and culture? Indeed, what is the Utopian imagination of late capitalism, or postmodernity? These questions are at the core of Fredric Jameson's brilliantly adroit latest book (the concluding volume of his Poetics of Social Forms series, with Verso). Part One comprises an extended, systematic interrogation of Utopian form (half of this happily weighty book). But Jameson's engagement with the Utopian problematic goes back to the early 1970s and Part Two of Archaeologies of the Future is a welcome collection of essays spanning four decades. Thus, at once a retrospective, as well as a newly envisioned intervention, Archaeologies stands alongside other works in Jameson's oeuvre (such as Marxism and Form, The Political Unconscious, and Postmodernity, Or, The Cultural Logic of Late Capitalism) in terms of the 
critical significance of its interrogation of the formal limits and (since form is always the form of a specific content) political possibilities of cultural forms generally, and Utopia specifically.

In this richly layered text, Jameson explores the (always historical) conditions of possibility for those politically ambiguous and peculiar fantasies that are 'the desire called Utopia' (p. 84). Mapping the terrain of Utopian form (rather than the more obvious mapping of content), he makes form itself palpable in all its dialectically twisty perplexity. He interrogates and proposes a theory of Utopian production: one that does not pass through content (i.e., those substantive, filled wishes of the Utopians, from geese that fly off the spit to the transcendence of money itself); one that does not capitulate to the perceived necessity of a late capitalism that 'seems to have no natural enemies' (p. xii); nor one that capitulates to the vacuous pluralism of the Utopia of Utopias (right libertarian Robert Nozick is among Jameson's targets here).

Indeed, and of importance to contemporary political theorists, inherent in this critical shift from content to form are the criteria that force us to banish liberal political theory from Utopia: 'the attempt to establish positive criteria of the desirable society characterizes liberal political theory from Locke to Rawls, rather than the diagnostic interventions of the Utopians' (p. 12). Utopia is to be read negatively; liberal theory is but 'the composition of blueprints for bourgeois comfort' (p. 12). And, Jameson argues, at stake in this shift from content to form is the very possibility of a Utopianism able to map, challenge, and transform the systemic totality of late capitalism.

Some critical manoeuvres in this complex argument: beginning with the distinction (from Ernst Bloch) between Utopian program and Utopian impulse, Jameson uncovers the ways in which achieved Utopian wishfulfilment is always necessarily the betrayal of the act of wishing itself, thus beginning the shift of critical attention away from what can be wished for to the formal properties of the act of wishing. In a wonderful discussion of Coleridge's Imagination (corresponding to the ability to perceive and map the systemic totality) and Fancy (corresponding to a gleeful indulgence in the detail of the quotidian), Jameson mirrors one of the paradoxes of Utopia: how can the impulse of rage against suffering (Adorno, always implicit, is marked out here) be made commensurate with the delightfully dilatory qualities of Utopian textual invention? Further, more broadly, the (political) problem of Utopia is the problem of oppositional or subversive art and culture in capitalism itself (Marcuse resonates here): as art is at once able to indict the evils of the existing order of things, its lowly status as culture, separated from political and economic realms, means its critique is felt 'feebly,' if at all. Further representational aporias include the temporality of the Utopian, or how to thematize transition and break (Jameson echoes 
Rousseau: 'the cause must become effect,' that is to say, to become the kinds of creatures who can live in Utopia, Utopia must somehow already exist). Utopia, then, cannot simply resolve the questions of a revolutionary break with the existent and the agency that undertakes this (Utopia cannot tell us what to wish for or how to fulfil those wishes). As Jameson put this in his 1982 essay (reprinted here): Utopia's 'deepest vocation is to bring home [...] our constitutional inability to imagine Utopia itself: and this, not owing to any individual failure of imagination but as a result of the systemic, cultural and ideological closure of which we are all in one way or another prisoners' (p. 289). Thus, Utopia's highest moment is this representational failure (the failure of content).

The engagement with science fiction (SF) is core to Jameson's argument. Indeed, the literary Utopia is defined as a 'socio-economic sub-genre of that broader literary form' ( $\mathrm{p}$. xiv). It is in SF, and its historical, materialist, and technological meditations on the alien (or radically other) that the Utopian problematic is given its sharpest articulation: 'what, then, if the alien body were little more than a distorted expression of Utopian possibilities? If its otherness were unknowable because it signified a radical otherness latent in human history and human praxis, rather than the not-I of a physical nature?' (p. 118). Staged in SF is the 'dialectic of Identity and Difference' that is core to Utopia: 'the Utopians not only offer to conceive of [...] alternate systems; Utopian form is itself a representational meditation on radical difference, radical otherness, and on the systemic nature of the social totality' (p. xii). The formalist meditation of Utopia thus marked as the problem of temporality (the revolutionary break) becomes the dilemma of how, or even can, we imagine communication with another system? (Certainly a salutary caution to Habermasians.) For the radically other that Utopia thematizes can only be post-human(ist): the radical alterity of the New means that all investments in the presently existent must give way; depersonalization (of the bourgeois subject), the event of the utterly other and unknown, is the terrifying promise of Utopia. (Let me note in passing Jameson's argument that the 'sublime terror' (p. 202) of the anti-Utopians is, not quite the fear of authoritarianism, but rather the fear of boredom in Utopia: elliptically expressed as the problem of what kind of art will such creatures create?)

The central aporia of the content of the Utopian imagination is reached thus: "the more surely a given Utopia asserts its radical difference from what currently is, to that very degree it becomes, not merely unrealizable but, what is worse, unimaginable' (p. xv). Jameson confronts one final objection: 'might there be a 'minimum formulation of Utopian demands which might somehow retain effective universality? Can we not envision some zero-degree Utopia, a Utopia in which content was reduced to its most undeniable validity for all societies?' (p. 172). The significance of this question 
to contemporary debates in political liberalism is evident; nevertheless, through an exploration of Adorno's 'crudest response,' that 'no one shall go hungry anymore' (p. 172), Jameson proposes that even the minimal Utopia 'vehiculates the most complexly historical themes and undertones' (p. 175); a content approach to Utopia can thus yield only the 'situated' or even 'distorted' and necessarily 'ideological' and 'self-bound' (pp. 170-171).

What, then, can be the truth-content of Utopia? And how can form resolve, or at least productively articulate, the contemporary role of Utopia? Is the solution a relativist pluralism - allow each Utopia in the global archipelago its 'moment of truth' (p. 175)? Resolutely not; and the fatal error here is, Jameson argues, to imagine that truth itself can be conceived as a positive, as a substantive: 'We do not use this concept properly unless we grasp its critical negativity as a conceptual instrument designed, not to produce some full representation, but rather to discredit and demystify the claims to full representation of its opposite number. The 'moment of truth' is thus not a substantive one, not some conceptual nugget we can extract and store away with a view towards using it as a building block of some future system' (p. 175). Crucially, the form of truth is the form of Utopia itself. If truth (drawing on Adorno) is radically negative, then its force is that of a diagnostic 'double negation'; Jameson delineates this via a welcome review of Bakhtin's 'carnivalesque' and Louis Marin's contribution to Utopian studies, the concept of the Utopian figure as 'neutralization': the figure which is neither substantively for or against, but which 'attempts to retain two negative or privative [features] along with their mutual negation of each other' (p. 180). Hence, in the contemporary moment of anti- (or alter) globalization, Jameson proposes that the formal flaw - how to articulate the Utopian break in such a way that it is transformed into a practicalpolitical transition - now becomes a rhetorical and political strength — in that it forces us precisely to concentrate on the break itself: a meditation on the impossible, on the unrealizable in its own right' as that which expresses our relationship to a 'genuinely political future' (p. 232). Such a future is conceived in terms of a complex alterity (c.f., Benjamin's Messianic interventions) that seeks to alter the totality of the present in entirely unexpected, utterly transformative, ways.

This is a dense and layered book (written, however, with an elegance of style; no word is extraneous). As with any excellent book, the reader finds herself engaged in an ongoing critical debate with its positions; to mention just one example, Jameson's (Marxist) averse appraisal of other forms of political struggle (e.g. feminist, post-colonial) may rile. Yet, Archaeologies is of huge importance to Utopian, literary, cultural, and philosophical studies; and its particular significance to contemporary political theory might very well be the 
ways in which it forces us to re-engage with the systemic totality (as that which can be transformed utterly) without reference to a universalism that may itself only homogenize. To sloganize: Vive la Différence! is the necessary heart of Vive la Révolution!

Susan McManus

Queen's University, Belfast, UK 